\title{
Taxila Mirrors Preserved in India and Technology Transfer
}

\author{
Pranab K Chattopadhayay* and Satyakam Sen**
}

\begin{abstract}
The mirrors excavated from Taxila are preserved in the collections of Museums of India and Pakistan. They are significant for information on the technological history of mirrors of the Indian subcontinent. The paper recapitulates the history of the site and excavations conducted in the past at Taxila. It also focuses on the metallurgical composition, manufacturing technique and other features like technology transfer.
\end{abstract}

Key words: Cire perdue, Mahal, Mirror-technology, Omphalos, Sirkap, Takṣaśilā.

\section{INTRODUCTION}

Taxila or Taksaśilā $\left(25^{\circ} 13^{\prime} 52^{\prime \prime} \mathrm{N}, 82^{\circ} 13^{\prime} 52^{\prime \prime}\right.$ $\mathrm{E})$, an ancient archaeological site, is situated in Rawalpindi district of Punjab, Pakistan. As per $\mathrm{C}^{14}$ dates settlement at Taxila (in the Hathial area) traces back to ca. 2550-2288 BCE. In ancient Indian literature, like Rāmâyana, it is referred to as a city founded by Bharata, who placed his son Taksha as its ruler. In Mahābhärata, it is mentioned that one of the successors of Pandava, ruler of Hastinapur - Janamejaya, performed the Snake-sacrifice at this place. According to Jātaka, Taxila was the capital of Gandhara and it was a great centre of learning, where princes as well as common folk participated in learning. The Achaemenid ruler, Darius I, annexed the province Gandhara of north western region in ca. 518 BCE and Taxila came under foreign domination during 486-465 BCE.

The Persian capital, Persepolis, was captured and destroyed by the Macedonian ruler Alexander in 330 BCE. At that time, Taxila was ruled by Ambhi (mentioned in Greek sources as Omphis) who surrendered to Alexander in $326 \mathrm{BCE}$, when the latter was in Taxila. The contemporary ruler Puru (Porus in Greek sources) ruled the land east of the Jhelum and opposed the movement of Alexander. Later, Chadragupta Maurya captured the North West in 325 BCE. Thus the Greek rule in Taxila was short-lived. Aśoka, the grandson of Chandragupta, was made governor of Taxila by his father Bindusara. The Taxila region was thus annexed under Mauryas, as mentioned in a major Aśokan rock edict found in the north of Mansehra village (Chakrabarti, 2011, pp. 51-52). The weak successors of Aśoka could not hold on to Taxila for long.

The last Mauryan ruler, Brihadratha, was assassinated by Pushyamitra Sunga in 185 BCE and that was the beginning of the Sunga dynasty.

In northern Afghanistan region, Bactria was in the possession of Indo-Greek rulers who built a new capital in Sirkap. Menander (165/155-130 $\mathrm{BCE}$ ) was ruled from Sakala (Sialkot). Taxila was one of the capitals of the Indo-Greeks and continued to grow with foreign successors. In 20 BCE Gandophares captured Taxila and founded Indo-Parthian rule. The Indo-Greek rulers were overthrown by a nomadic tribe of central Asia, the Scythians (Śakas) in $1^{\text {st }}$ century BCE for a short period, as also by the Parthians from eastern Iran. The region was further captured by the Kushan

\footnotetext{
* Mission Palli, Sonarpur, Kolkata-700150, Email: pranab.chattopadhyay@gmail.com.

**Sr. Technical Assistant, Archaeology Section, Indian Museum, Kolkata-700016, Email: satyakamsen@gmail.com.
} 
tribes of Central Asia, under Kujula Kadphises in 76 CE. When Kanishka I came to the throne in 78 CE, Taxila was one of the capitals of the Kushans. In 460-470 CE the Huns captured the region and destroyed most Buddhist monasteries and stupas. Kanishka founded a third city, at Sirsukh.

Ruins of Taxila were discovered in an extensive valley between the Jhelum and the Indus. The remains were first identified as those of Taxila by Sir Alexander Cunningham who visited there in 1863-64 and 1872-73. From 1913 to 1934, on behalf of Archaeological Survey of India, Sir John Marshall extensively excavated the regions at Sirkap and Bhir Mound. The capital had been first established at Bhir Mound, and then shifted to Sirkap. In 1944-45, Sir Mortimer Wheeler conducted small scale excavations in those city sites. Numerous Buddhist establishments were discovered in the region. Fig. 1 indicates the location of Taxila along with the major Harappan sites (Google map) while Fig. 2 is the site map of Taxila, showing Sirkap and other sites (https:// en.wikipedia.org/wiki/Sirkap).

Chronologically, the Bhir Mound site of Taxila is dated to $5^{\text {th }}$ century BCE. The Indo-Greeks, under Demetrius, had built a new capital for

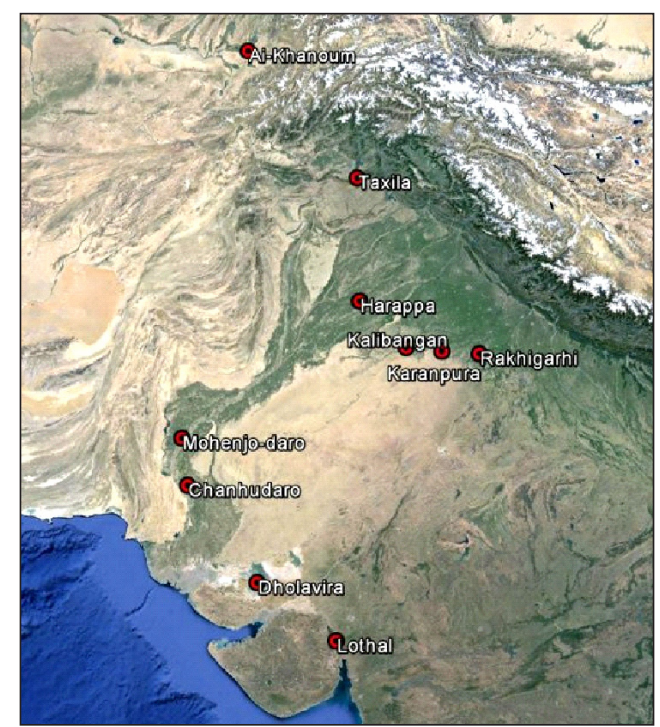

Fig. 1 Google Map of Harappan sites of India and Pakistan showing the location of Taxila.

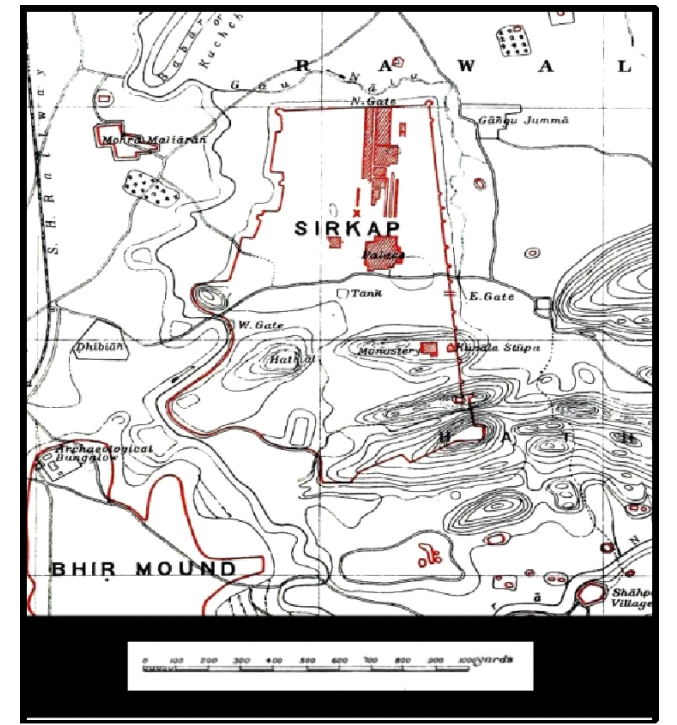

Fig. 2 Map of Taxila, showing Sirkap.

themselves, now known as Sirkap, in $2^{\text {nd }}$ century BCE. The third identified city was Sirsukh, which was where the capital had shifted under the Kushanas. Bhir Mound and Sirkap are separated by a stream named Tamra Nalla. Another site has been incorporated in the ruins (Marshall, 1960, pp.82-84) of the lower city of Sirkap that includes an interesting group of buildings at a spot called 'Mahal', situated on a high ground in a dip between the rocky ridges at the western end of the Hathial spur. The word 'Mahal' signifies a royal residence and it has perpetuated a genuine tradition for the elevated but sheltered position which the building occupies. With its sunny aspects and fine commodities, with a view to the west, it would have been admirably suited for a royal winter residence. The buildings were planned on a scale comparable to that of the lower city. According to the excavator, Mahal residence was occupied in $1^{\text {st }}$ century $\mathrm{CE}$, as confirmed from the masonry.

The most important information from the Taxila site was the discovery of around sixty metallic vessels, along with other antiquities. Those were revealed from the hidden recesses between the small rooms. The objects included beakers, bowls, saucers, ladles and mirrors. From the accession 
register and the label on the packet NS 3984/ A9312, it could be rightly confirmed that one of the bronze mirrors in the Indian Museum collection was a part of that hoard of Mahal.

We are tempted to mention that the collection also include a fine handled jug of Hellenistic pattern, a perfume holder of polished agate and a conical Assyrian pot. Marshall further mentioned the inscription on one of the copper ladles suggested that it was brought to Taxila from the monastery of Kasyapyas at Bedali, 60 miles (96.56 $\mathrm{km}$ ) north of the city, by monks fleeing before the advancing armies of Kushanas (Marshall, 1975R, p. 80).

This most important ancient Indian site has reported the discovery of not only distillation and surgical equipment but also various types of metallic and non-metallic antiquities. The former mentioned equipment has enriched the Indian Museum. Marshall had mentioned the mirror from that site that described the existence of several specimens.

\section{TAXila Mirrors as described by Marshall}

Marshall (1951) considers Taxila mirrors dating back to as $4^{\text {th }}$ century BCE. A few mirrors were obtained from Sirkap: strata III, IV and II. Marshall further commented, those mirrors were found only in the Śaka-Parthian city in Sirkap and were copied from Western prototypes. They consist of a circular disk, 72 to $165 \mathrm{~mm}$ in diameter, furnished with a tang at the base fitted into bone, ivory or wooden handles. According to him, the faces of the mirrors were smooth and slightly convex; whereas the back sides of the specimens were sometimes plain, but more frequently relieved with a broad wavy rim and a raised boss or omphalos (in Greek and Roman) in the centre. None of these mirrors were decorated. One such object was found decorated with a female figure in relief(Marshall, 1951, p.135, ibid

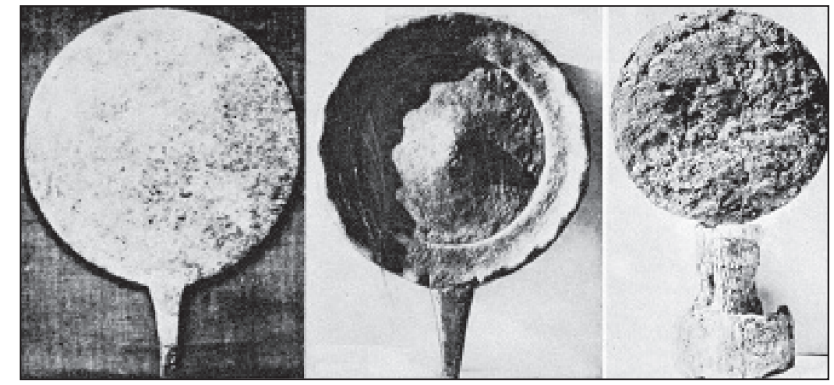

Fig. 3 Excavated Mirrors from Taxila: nos. 208, 209 and 211 as mentioned by Marshall.

43, plate 203k). Fig. 3 indicates three mirrors excavated from Taxila.

It is known that a number of Harappan mirrors and other antiquities are available in different museums of India and Pakistan. We have some information of mirrors from Harappan sites, which were revealed during excavation or chance finds, but the details are not available in published forms. The best collection of Taxila mirrors are in the possession of Taxila Institute of Asian Civilizations, Quaid-i-Azam University, Islamabad, and National Museum in Karachi both in Pakistan. In India there are only four mirrors - one at the National Museum, New Delhi and three specimens at Indian Museum, Kolkata. An introductory paper on Taxila mirrors was published earlier (Chattopadhyay and Sen, 2016).

\subsection{Taxila Mirror in National Museum of Pakistan}

National Museum of Pakistan, Karachi was established in 1950 and the collection of this museum began with the antiquities of Indus Valley, Gandhar and other sites. One of the most important antiquities of the museum is a mirror with an ivory handle (accession number 2043 SK' 143/10). The photograph produced here (Fig. 4) is copy righted by Robert Harding Picture Library Ltd (No 111901).

\subsection{Sirkap Mirror in National Museum, New Delhi}

National Museum of India was established in 1949 in New Delhi. It possesses a mirror specimen 


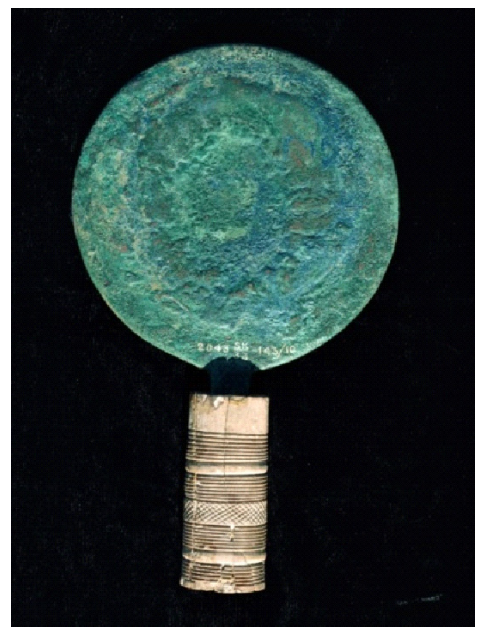

Fig. 4. Mirror from Taxila in National Museum of Pakistan, Karachi.

from Taxila with accession number 2687- sk-22645/7 (Fig. 5). This mirror was obtained from DG, Archaeological Survey of India on $15^{\text {th }}$ February 1960. The total length or height of this mirror is $194 \mathrm{~mm}$, including the face and tang. The tang or handle is $46 \mathrm{~mm}$; the face of the mirror is slightly concave. At the back, there is a broad raised rim around the edge, about $20 \mathrm{~mm}$ in breadth (shown in the former figure), and in the centre it has a raised boss which is not sharp. At the base of the mirror is a tang which had probably fitted into a handle. That mirror is oval with $148 \mathrm{~mm} \times 143$ mm size.
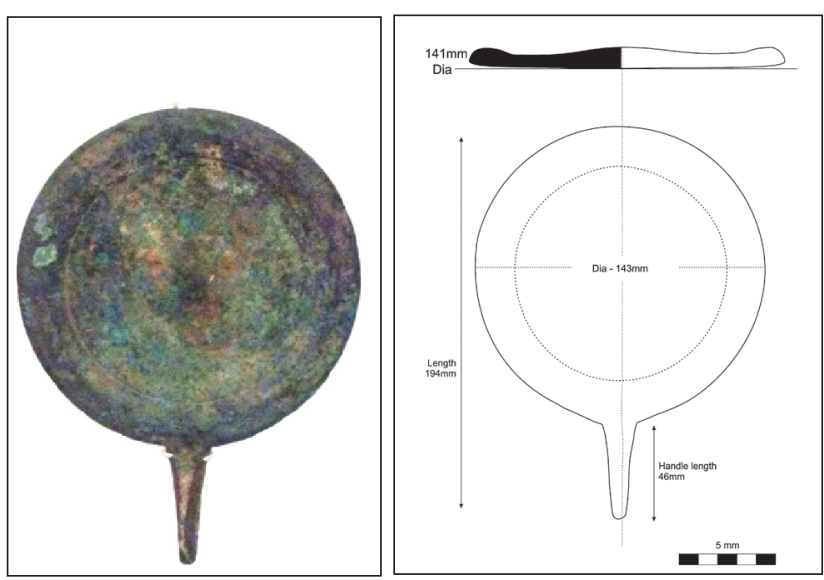

Fig. 5 Backside of Taxila mirror and its engineering drawing, National Museum, New Delhi.

\subsection{Mahal Mirror in Indian Museum, Kolkata}

Indian Museum, the largest and oldest museum in the Indian subcontinent, was established by the Asiatic Society of Bengal in 1814. It has three mirror specimens from Taxila; all were obtained from DG, Archaeological Survey of India. The first mirror specimen from Mahal (Taxila) was obtained on $20^{\text {th }}$ February 1923. Its registration number is N.S. 3984/ A9312 (Fig. 6). The total length or height of this mirror is $192 \mathrm{~mm}$, including the face and tang. The face of this mirror is a circular disc, slightly convex, $141 \mathrm{~mm}$ in diameter and having a thickness of $5 \mathrm{~mm}$. The backside has a rim of about $19 \mathrm{~mm}$ in breadth and a raised boss or omphalos in the centre, with maximum thickness of $6 \mathrm{~mm}$. Its weight is $0.465 \mathrm{~kg}$. The tang is almost ' $\mathrm{V}$ ' shaped, $52 \mathrm{~mm}$ in length, 16 $\mathrm{mm}$ in breadth at top, and $5 \mathrm{~mm}$ at bottom. It was presumably attached to an ivory, bone or wooden handle.
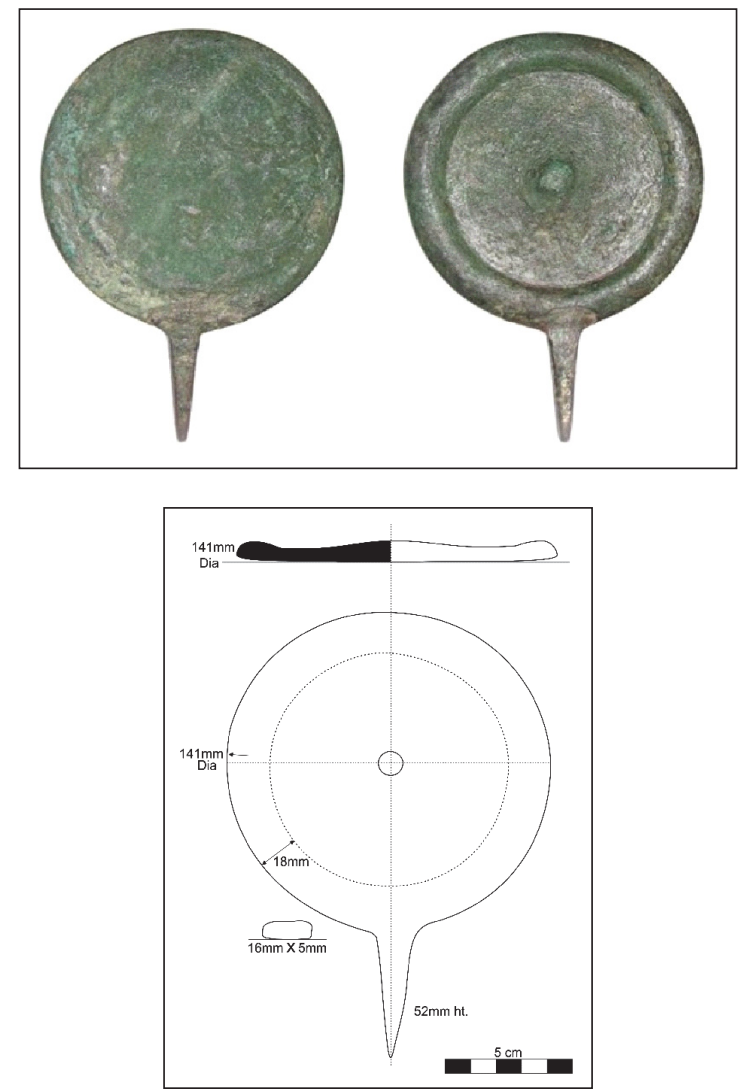

Fig. 6 Mirror from Mahal and its Engineering drawing in Indian Museum, NS 3984/ A9312. 

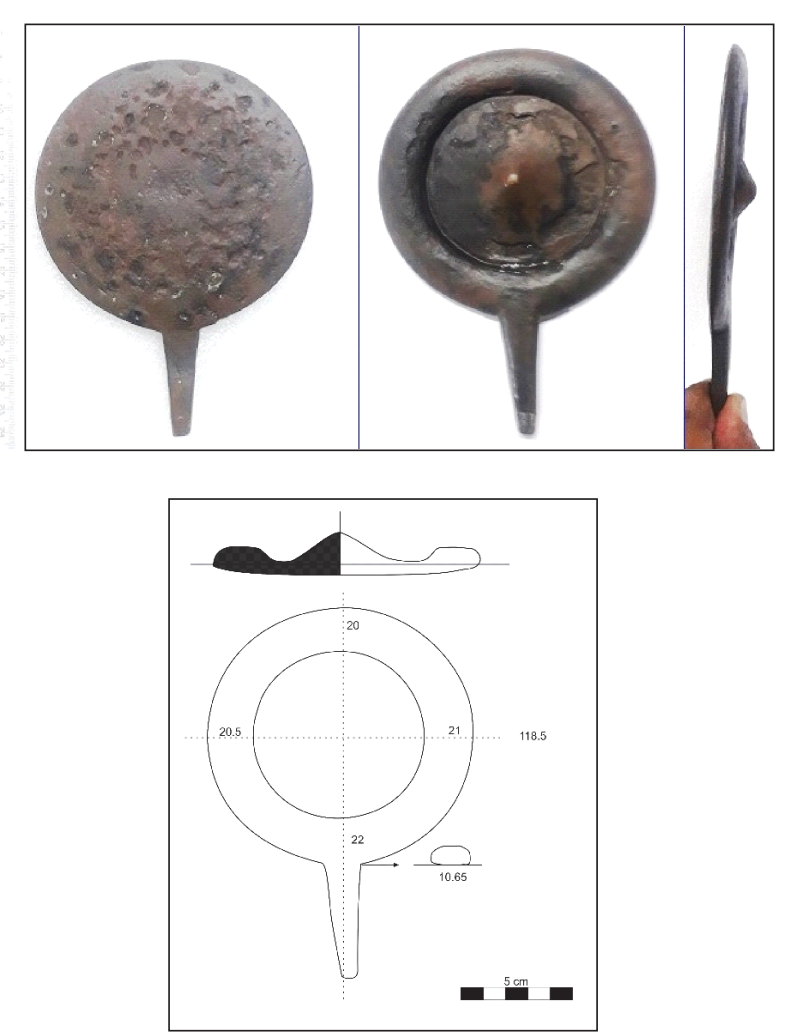

Fig. 7 Mirror from Sirkap and its Engineering Drawing: Indian Museum 9934/ A9305.

\subsection{Mirrors from Sirkap: Indian Museum}

Two mirrors from Sirkap are available in the Indian Museum collection in Kolkata. The date of entry of both these mirrors (D.O.E) is $19^{\text {th }}$ November 1936. The face of the mirror is convex in shape. Both the sides are corroded with severe pits. The specimen, accessioned as number 9934/ A9305, shown in Fig. 7, is sliver brown in colour. This specimen was made with copper-bronze alloy. Its weight is $0.490 \mathrm{~kg}$. The total length of this mirror is $163 \mathrm{~mm}$ - that includes the face and tang. This mirror possesses the largest raised boss or omphalos. The backside is having a rim of about $18 \mathrm{~mm}$ in breadth and a raised boss or omphalos in the centre - maximum thickness of it is $7 \mathrm{~mm}$. The face of the mirror is convex in cross section with a breadth of $138 \mathrm{~mm}$. The tang of this mirror is $49 \mathrm{~mm}$ in height. The breadth of tang is max at the joint of the mirror face which is $15 \mathrm{~mm}$. Otherwise it is $\mathrm{V}$ - shaped with minimum size of 8 $\mathrm{mm}$ at the bottom. The maximum thickness of the tang is $6 \mathrm{~mm}$ to $3.5 \mathrm{~mm}$ at the bottom. The specimen was found with corrosion pits. Omphalos is well represented in this mirror. The tang, rim, omphalos and other components are clearly represented in the cross section of this mirror as shown in the engineering drawing.

The specimen 9933/A10496 and its engineering drawing shown in Fig. $8 \& 9$, is pistachio green in colour. The total height of face and the tang is $185 \mathrm{~mm}$. The backside has a rim of about $16 \mathrm{~mm}$ in breadth and a thin raised boss or omphalos in the centre, the maximum thickness of which is $6 \mathrm{~mm}$. The boss of this mirror is the

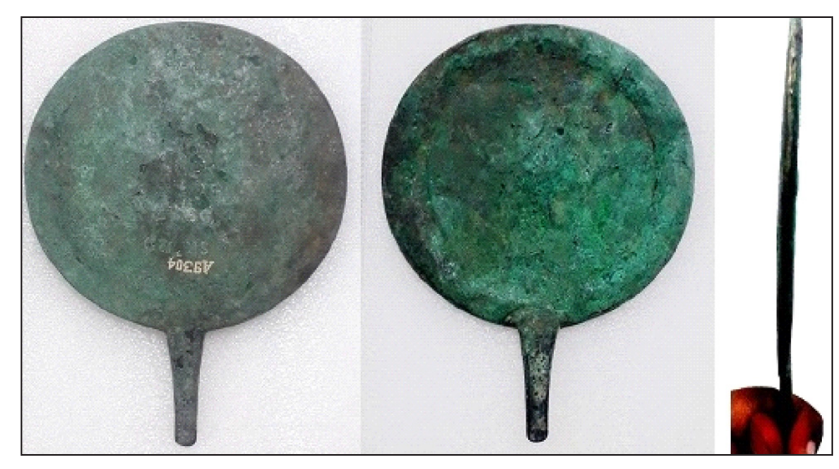

Fig. 8 Specimen 9934/A9305: Face side (left), back side (centre) and side view (right), showing the sharp omphalos, Indian Museum Kolkata).

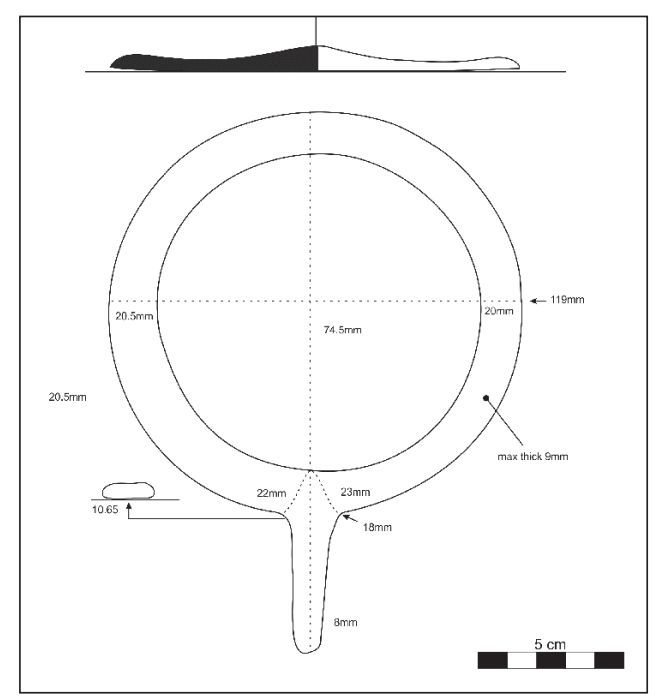

Fig. 9 Engineering drawing for specimen 9933/ A9304. 
Table 1. Mirrors of Taxila in India (Weight in $\mathrm{Kg}$, dimensions is in $\mathrm{mm}$ ).

\begin{tabular}{|llllllllll|}
\hline Origin & $\begin{array}{l}\text { Present } \\
\text { Location }\end{array}$ & $\begin{array}{l}\text { Accession } \\
\text { No }\end{array}$ & DOE & Wt/Kg & Dia./ & $\begin{array}{l}\text { Length/ } \\
\text { width }\end{array}$ & $\begin{array}{l}\text { Thick } \\
\text { height }\end{array}$ & $\begin{array}{l}\text { Handle } \\
\text { length }\end{array}$ & $\begin{array}{l}\text { Handle } \\
\text { breadth }\end{array}$ \\
\hline Sirkap & $\begin{array}{l}\text { National } \\
\text { Museum }\end{array}$ & $2687-$ sk-22-645/7 & $15 / 02 / 1960$ & 0.3588 & $143 \mathrm{~mm}$ & $194 \mathrm{~mm}$ & & $46 \mathrm{~mm}$ & \\
& & & & & & & & \\
Mahal & $\begin{array}{l}\text { Indian } \\
\text { Museum }\end{array}$ & NS 3984/ A9312 & $20 / 02 / 1936$ & 0.465 & $141 \mathrm{~mm}$ & $192 \mathrm{~mm}$ & $5 \mathrm{~mm}$ & $52 \mathrm{~mm}$ & $\begin{array}{l}16 \mathrm{~mm}- \\
5 \mathrm{~mm}\end{array}$ \\
Sirkap & $\begin{array}{l}\text { Indian } \\
\text { Museum }\end{array}$ & $9934 /$ A9305 & $19 / 11 / 1936$ & 0.490 & $138 \mathrm{~mm}$ & $163 \mathrm{~mm}$ & $7 \mathrm{~mm}$ & $49 \mathrm{~mm}$ & $\begin{array}{l}18 \mathrm{~mm}- \\
8 \mathrm{~mm}\end{array}$ \\
Sirkap & $\begin{array}{l}\text { Indian } \\
\text { Museum }\end{array}$ & $9933 /$ A9304 & $19 / 11 / 1936$ & 0.450 & $173 \mathrm{~mm}$ & $185 \mathrm{~mm}$ & $6 \mathrm{~mm}$ & $50 \mathrm{~mm}$ & $6 \mathrm{~mm}-$ \\
& & & & & & & & $3.5 \mathrm{~mm}$ \\
\hline
\end{tabular}

thinnest and blunt, having lost its content due to corrosion. Its weight is $0.450 \mathrm{~kg}$. The rearside of the mirror has a rim of about 20 to $23 \mathrm{~mm}$ in breadth and the thickness of the rim is $16 \mathrm{~mm}$. This mirror possesses the thin raised boss with maximum thickness of $7 \mathrm{~mm}$. The face of the mirror is convex in cross section with a breadth of $173 \mathrm{~mm}$. The tang of this mirror is $50 \mathrm{~mm}$ in height. The breadth of tang is max at the joint of the mirror face and is $18 \mathrm{~mm}$. It is $\mathrm{V}$ - shaped with maximum size $8 \mathrm{~mm}$ at the bottom and six sided in cross section. The maximum thickness of the tang is $6 \mathrm{~mm}$ to $3.5 \mathrm{~mm}$ at the bottom.

Details of known Taxila mirrors in India have been incorporated in Table 1.

\section{Mirror Handles from Taxila}

While discussing mirrors, one should not forget the essential accessory of its attachment - the handle. Even in stone sculpture or terracotta, handles are clearly represented. Mirrors are mostly found with handles, which are connected with tangs, the bases of which are fitted into bone, ivory or wooden handles. Those are shown in Fig. 10. Ivory handles attached to mirrors were reported from Ropar, Hastinapura, Vaisali, Nevasa and other sites, and have been incorporated elsewhere (Ghosh, 1989, p. 348). A mirror with shell handle is in the display of Late Ramlingappa Lamture Government Museum in Ter, Maharashtra (personal communication Dr. Mayur Thakre, Directorate of Archaeology and Museums, Govt. of Maharastra). Those handles are attractive art objects. Most of the mirrors throughout the period include handles. In case of Harappan mirrors, handles attached to them were in-built, manufactured by the same process of making face. Most of the mirrors of Taxila were accompanied by a tang and which was used to fix it to a handle made with ivory, bone or wood. Unfortunately no mirror handle was found with the Indian

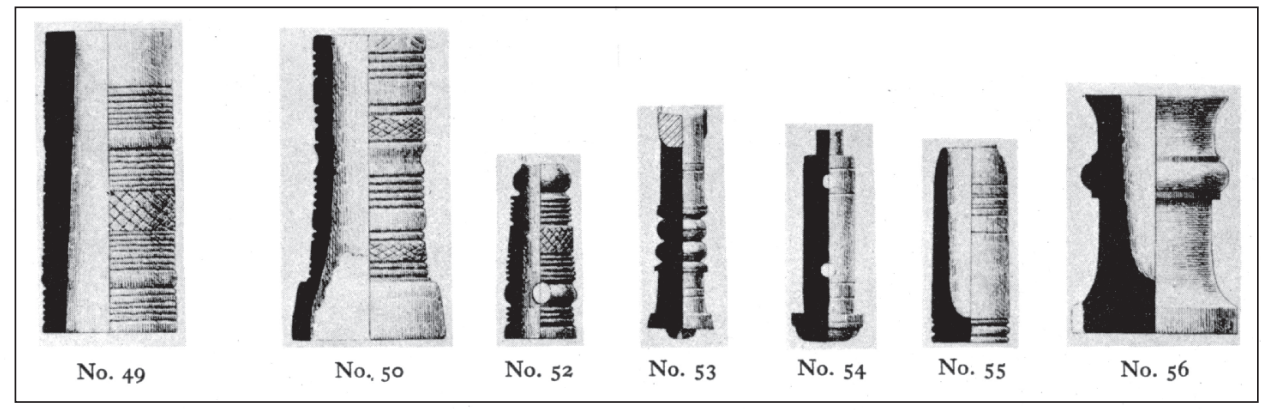

Fig. 10 Mirror handles from Taxila: After Marshal. 
specimens as mentioned. Only the National Museum Pakistan, Karachi's specimen, as shown in Fig. 4, has an ivory handle. Several mirrors with ivory handles are known from Taxila Institute of Asian Civilizations, Islamabad.

\section{Metallurgical Analyses}

Marshall (1951) has given the analysis of a mirror from Taxila, which was made of high tin bronze with $25 \% \mathrm{Sn}$. Since forging of high tin bronze was not known to the Taxila smiths, we presume that it was made by casting the ingot first. Unless and until metallography was done, one could not have identified whether forging was done as the mirror blank; definitely the surface or the mirror face was made by polishing with sand and smooth river clay. Two mirrors that were analyzed indicated the use of high tin bronze or $k \bar{a} n s ́ a$. High tin bronze was also used in a bell retrieved from the same site (Table 2). Mirrors throughout the period include handles. We have not yet been able to identify the present locations of the two mirrors, nos SK'33-143/10 and SK'141385 .

\section{Contributions of Metal Smiths of Taxila}

While discussing these mirrors, we would like to delve into the composition of these metal objects and their alloying pattern. The copper-bronze objects recovered here were duly analyzed and interpreted by the pioneer archaeo-chemists, Mohammad Sanaullaha and Dr M A Hamid and included in the excavation report (Marshall, 1975R, pp. 564-606). The copper bronze objects from Taxila further revealed that two types of alloying were practiced by the smiths of Taxila. First category includes soft copper-where tin percentage was less than 0.74 . Unalloyed copper (i.e. pure copper) was never cast in Taxila. The second category includes high tin bronze without the presence of lead. Tin content in 9 out of 11 bronze specimens are between 21.55 to $25.59 \%$.

Taxila metal smiths had developed convex mirror face added with typical tang to join the handle (a few $\mathrm{V}$-shaped), having a rim with a raised omphalos. This typology in mirror making was spread in different Mauryan and postMauryan sites in northern parts of the subcontinent perhaps through the traders. Important sites with exactly similar typology are Rairh of Rajasthan (Puri, 1926-27); Bulandi Bagh, Patna (Page, 1926-27); Chandraketugarh (Chattopadhyay, 2002, pp. 451-61) and Mahasthan (Salles et al., 2002, pp. 533-556) of Bengal and a few others. They clearly represent that those were typologically similar to the findings of the Taxila mirrors. In case of Sri Lanka, one must look into findings of excavations at the Citadel of Tissamaharama. A bronze mirror was excavated from this site with a central boss, with thickened edge or rim, dated to $2^{\text {nd }}$ century BCE (Weisshaar, 2015, pp. 208-228). The mirror was found in the filling of a small channel dated to the $2^{\text {nd }}$ century $\mathrm{BCE}$ from phase $\mathrm{c} 1$. Two ivory handles used with the mirror were also recovered during excavation at this site.

Table 2. Chemical Analyses of Taxila Mirrors (Analysis conducted by Sanaullaha as quoted in Marshall, 1951).

\begin{tabular}{|c|c|c|c|c|c|c|c|c|c|}
\hline \multirow[t]{2}{*}{ Site (Level) } & \multirow[t]{2}{*}{ Accession No } & \multirow[t]{2}{*}{ Time Period } & \multirow[t]{2}{*}{$\mathrm{Cu}$} & \multicolumn{6}{|c|}{ Major elementsOther than $\mathrm{Cu}(\mathrm{Wt} \%)$} \\
\hline & & & & As & Sn & $\mathbf{Z n}$ & $\mathbf{S b}$ & $\mathbf{F e}$ & $\mathbf{N i}$ \\
\hline Taxila, Sirkap & SK'33-143/10 & $1^{\text {st }} \mathrm{c} . \mathrm{CE}$ & 74.61 & 0.11 & 22.0 & - & & 0.71 & 0.47 \\
\hline Taxila, Sirkap & SK’14-1385 & $1^{\text {st }} \mathrm{c} . \mathrm{BCE}$ & 74.28 & 0.04 & 24.85 & - & 0.12 & 0.71 & \\
\hline Taxila Bell & SK'30-216 & $2^{\text {nd }}$ c. $B C E$ & 74.80 & 0.10 & 24.14 & - & 0.20 & 0.55 & \\
\hline
\end{tabular}




\section{Technology Transfer}

Earliest evidence of mirrors is known from Anatolia-Çatalhöyük. From Armenia, an early discovery of metallic mirror has been traced, belonging to Middle Bronze Age (Avetisian et al., 2000). In Pakistan, India, Bangladesh and Sri Lanka subcontinent, wide use of mirrors was initiated in Harappan sites in Southeast Asia. The use of mirrors began in mature Harappan Phase, 2600-1900 BCE. Most of the mirrors from Harappan sites were recovered from the burials. It is also known that most of the burials were disturbed by the burial hunters, or rather, graverobbers. That is the reason for incomplete information about the mirrors used by the Harappan women (During Caspers, 1996).

Harappan culture had developed very fast with their metallurgical skills. From oxide and sulphide ore-minerals, the Harappans could extract copper, and learnt to make low tin bronze alloy, as also alloys with arsenic, nickel and lead. Harappans knew the techniques of closed casting and Cire Perdue - a process used in metal casting that consists of making a wax model of the proposed product, also called lost wax casting. Besides other techniques, forging and joining were also known to them. Those techniques included sinking, raising, running on, cold-forging, annealing, riveting, lapping and a few others (Agrawal, 1971).

Regarding technology, two techniques might have been employed by Harappans to make mirrors - forging the mirror blank straight from copper-bronze ingots, then grinding and polishing the mirror surface; or the second technique of casting the mirror blank then subsequent finishing techniques. The second technique is easier and has been experimentally reproduced by Jonathan Mark Kenoyer (Personal communication, 20 ${ }^{\text {th }}$ May 2015). He reproduced a mirror by using sand bivalve mould and finished those with grinding and polishing. Thus the manufacturing technique has been established clearly.
Most of the Harappan mirrors include the broad handles - those were never found with complete finishing by casting; whereas Taxila mirrors were made basically by casting process. The basic manufacturing process was definitely casting and that is represented with tangs, omphalos and rim. First of all, knobs are found on the back side of Taxila mirrors. None of the Harappan mirrors has a knob. Front side of the mirror is flat. While casting a mirror, liquid metal is poured from the back side. For uniform metal flow to the body of the mirror, excess metal is poured. During solidification of metal, volume decreases and that extra liquid metal from the knob supplies the metal, and the volume is adjusted from that portion. This afore-mentioned knob is the raised boss at the centre. The sharp tang was attached further with ivory, bones or at least made with wooden handle.

Recent research by Vassilkov, 2010 and 2018, indicates that the technology of high-tin bronze hot forging most probably "came from India to the Southern Urals in the $4^{\text {th }}$ century BCE". He has rightly predicted that the parallels between the compositions on the "musical mirrors" and the early Indian art, outlined previously by some Russian authors, have led them to believe that the technology transfer originated from India. From the illustration it is clear that omphalos and rims used in Taxila had farther developed in Altai region, in sharpness as well as in use of double rims. Scythian or Sarmatian craftsmen were able to produce those artistic mirrors themselves, using a new technology, borrowed from far-off India.

Since the use of mirrors was initiated by the Harappans in 2600-1900 BCE, the Taxila mirrors came much later, in the $4^{\text {th }}$ Century BCE. However, in the latter, the typology was modified especially the handles, which were made of decorated ivory, bone or wood. These find mention in the Sodaś Mahājanapadās of northern India. Taxila mirrors were significant enough for their manufacturing technology to be transferred to far-flung places 
like Russia. This gives the Taxila mirrors a special position among the mirrors of ancient Indian subcontinent.

\section{ACKNOWledgement}

Authors acknowledge the kind support of Jayanta Sengupta, former Director and Shri Rajesh Purohit, present Director, Indian Museum, Kolkata for permitting us to study the mirrors of Indian Museum. Buddha Rashmi Mani, Sanjib Kumar Singh and Pooja Kushwaha of the National Museum, New Delhi have extended their support to study the mirrors of their collection. We are indebted to Prabodh Shirvalkar of Deccan College who taught us the techniques of drawing the archaeological specimens using softwire. Last but not the least Nandini Bhattacharjee has helped us with meaningful suggestions for improving the paper. Indian Museum and National Museum's mirror photographs are copy righted by them and we have obtained by their 'Courtesy'.

\section{Bibliography}

Agrawal, D P. The Copper Bronze Age in India, Munshiram Manoharlal, New Delhi, 1971.

Avetisyan, P, Badalyan, R; Gevrkyan, A and Khnkikyan, O. The 1998 Excavation Campaign at the Middle Bronze Age Necropolis of Sisan Armemia; in Estratto da, Studi Micenei Ed Egio-Anatolia, Roma: CNR Istituto per GLI Studi Mcnei Ed Egio-Anatolici (2000):161173.

Chakrabarti, D K. Royal Messages by the WaysideHistorical Geography of the Asokan Edicts, Aryan Books International, New Delhi, 2011.

Chatterjee, S; Naher, Sabikun and Chattopadhyay, P K. Mirrors of Ancient India: From Harappa to Mahasthangarh, Puratattva 45(2016):165-177, plate 18-19.

Chattopadhyay, P K and Sen, Satyakam. Mirror from Taxila: Specimens in Indian Museum Collection, Icon Journal of Archaeology and Culture, 3(2016):1-4 and pp. 229231.
Chattopadhyay, P K. Metal finds from Chandraketugarh, West Bengal: Archaeotechnical Studies in Sengupta G. \& Panja S. (eds) Archaeology of Eastern India: New Perspectives, Centre for Archaeological Studies and Training, Eastern India, Kolkata, 2002.

During Caspers, E C I. The reliability of archaeological evidence for mercantile/ intercultural contacts between Central and South Asia, the Arabian Gulf, and the Near East in the late third and early second millennium B C E. in Mitra Debala (ed) Explorations in Art and Archaeology of South Asia, Directorate of Archaeology and Museums, Government of West Bengal, Calcutta,1996, pp.123-156.

Ghosh, A. (ed.). An Encyclopaedia of Indian Archaeology, Munshiram Manoharlal Publishers Private Ltd, New Delhi, 1989.

Marshall, J. Taxila, Minor Antiquities, vol. 2, University Press, Cambridge, 1951, Reprint: Motilal Banarsidass, Delhi, 1975.

Page, J A. Bulandi Bagh Annual Report Archaeological Survey of India, 1926-27, pp.135-140.

Puri, K N. Excavations at Rairh, 1938-1940, Publication Scheme, Jaipur, (Reprint 1998).

Salles, J F; Boussac, M F and Breuil, J Y. Mahasthangarh (Bangladesh) and the Ganges Valley in the Mauryan Period, Sengupta, Gautam and Panj, Sheena (ed). Archaeology of Eastern India: New Perspectives, Centre for Archaeological Studies and Training, Eastern India, Kolkata, 2002.

Vassilkov, Y V. Pre-Mauryan "Rattle-Mirrors" with Artistic Designs from Scythian Burial Mounds of the Altai Region in the Light of Sanskrit Sources, Electronic Journal of Vedic Studies, vol. 17.3 (2010), www.ejvs.laurasianacademy.com.

Vassilkov, Y V. Five Indian 'Musical' Mirrors from Scythian and Sarmatian Barrows of Altai Region and South Urals, Russian Federation, Icon Journal of Archaeology and Culture, (2018):1-7.

Weisshaar, Hans-Joachim. Ancient Tissamaharama: The Formation of Urban Structures and Growing Commerce, Tripathi, S (ed.). Maritime Contacts of the Past: Deciphering Connections amongst Communities, Delta Book World, New Delhi, 2015. 